\title{
PENGARUH EPS,ROE, DAN STRUKTUR KEPEMILIKAN INSTITUSIONAL SAHAM TERHADAP HARGA SAHAM (Studi Pada PERUSAHAAN ROKOK yang LISTING di BEI TAHUN 2005-2011)
}

\author{
Disusun Oleh: \\ Nuraeni \\ Dosen Jurusan Ilmu Administrasi Niaga FISIP Universitas Yudharta Pasuruan
}

\begin{abstract}
ABSTRAKSI
Penelitian ini bertujuan untuk mengetahui apakah earning per share (EPS), return on equity (ROE) dan kepemilikan institusional berpengaruh terhadap harga saham perusahaan rokok yang listing di BEI periode 2005-2011. Sampel penelitian diambil secara purposive sampling. Model analisis data yang digunakan adalah analisis regresi linier berganda. Hasil penelitian ini menunjukkan bahwa hanya ada satu variabel bebas yang berpengaruh signifikan, yaitu variabel EPS. Hasil regresi secara keseluruhan $R^{2}$ square sebesar 0,862 yang berarti bahwa pengaruh variabelearning per share (EPS), return on equity (ROE) dan kepemilikan institusional terhadap harga saham sebesar 86,2\%.
\end{abstract}

kata kunci: Earning per Share (EPS), Return on Equity (ROE), Kepemilikan Institusional, Harga Saham.

\section{PENDAHULUAN}

Pasar modal memiliki peran penting dalam kegiatan ekonomi, terutama di negara yang menganut sistem ekonomi pasar. Pasar modal juga menjadi salah satu sumber kemajuan ekonomi karena dapat menjadi alternatif bagi perusahaan disamping bank. Perusahaan dapat dengan mudah untuk mendapatkan modal dengan biaya yang relatif murah dan juga sebagai tempat untuk investasi baik jangka pendek maupun jangka panjang. Investasi merupakan komitmen atas sejumlah dana atau sumber dana lainnya yang dilakukan pada saat ini dengan tujuan memperoleh sejumlah keuntungan dimasa yang akan datang. Pengambilan keputusan investasi memerlukan pertimbangan dan analisis yang mendalam untuk menjamin keamanan dana yang di investasikan serta keuntungan yang diharapakan (Kamaruddin, 2004). Untuk itu Seorang investor akan melakukan analisis terhadap harga saham yang akan dibelinya dengan tujuan untuk mengetahui kualitas, prospek dan tingkat resiko saham-saham tersebut.

Harga saham selalu mengalami perubahan setiap harinya, bahkan setiap detik harga saham dapat berubah. Harga saham merupakan hasil pembagian antara modal dan jumlah saham yang disebut harga nominal, pada saat emiten menerbitkan saham (Dominic, 2008). Harga saham suatu perusahaan mencerminkan nilai perusahaan dimata para investor, apabila harga saham suatu perusahaan tinggi, maka nilai perusahaan dimata investor juga baik dan begitu juga sebaliknya, oleh karena itu harga saham merupakan hal yang penting bagi perusahaan. Oleh karena itu, investor harus mampu memperhatikan faktor-faktor yang mempengaruhi harga saham. Faktorfaktor yang dapat mempengaruhi fluktuasi harga saham dapat berasal dari faktor internal dan eksternal. Adapun faktor internalnya, antara lain adalah 
laba perusahaan, aktivitas tahunan, likuiditas, nilai kekayaan total dan struktur kepemilikan saham. Sementara itu, faktor eksternalnya adalah kebijakan pemerintah dan dampaknya, pergerakan suku bunga, fluktuasi nilai tukar mata uang (Taratanika, 2009).

$$
\text { Earning per Share(EPS) }
$$

memberikan informasi tentang suatu perusahaan mengenai besarnya laba bersih perusahaan yang siap dibagikan pada semua pemegang saham. EPS merupakan salah satu hal utama yang diperhatikan investor sebelum membuat keputusan investasinya di suatu perusahaan karena investor tentunya mengharapkan pengembalian atau return yang tinggi dari investasinya sehingga investor akan lebih tertarik untuk berinvestasi di perusahaan yang mempunyai EPS lebih tinggi. Apabila EPS suatu perusahaan dinilai tinggi oleh investor, maka hal ini akan menyebabkan harga saham perusahaan tersebut cenderung bergerak naik (Taratanika, 2009).

Indikator lainnya yaitu Return on Equity (ROE), rasio ROE digunakan untuk mengukur kemampuan modal dalam menghasilkan pendapatan. ROE menggambarkan kemampuan modal sendiri untuk menghasilkan keuntungan bagi pemegang saham, karena dalam ROE yang digunakan sebagai pengukur efisiensi adalah besarnya laba bersih dari jumlah modal yang digunakan perusahaan. Jadi, ROE merupakan tingkat hasil pengembalian investasi bagi pemegang saham (Sa'diyah, 2010).Artinya semakin besar ROE semakin baik pula manajemen perusahaan karena dari modal yang dikelolah di hasilkan pendapatan yang optimal.

Selain kinerja keuangan, struktur kepemilikan saham pada suatu perusahaan juga mempengaruhi naik dan turunnya harga saham. Struktur kepemilikan saham di bagi menjadi dua kelompok yaitu kepemilikan saham secara manajerial dan kepemilikan saham secara institusional. Kepemilikan manajerial yaitu proporsi pemegang saham yang secara aktif ikut dalam pengambilan keputusan perusahaa. Sedangkan yang dimaksud kepemilikan Institusional adalah kepemilikan saham perusahaan yang dimiliki olehinsttusi atau lembaga seperti perusahaan asuransi, bank, perusahaan institusi lain (Tarjo: 2008). Kedua jenis struktur tersebut sama-sama mempunyai pengaruh terhadap pergerakan harga saham, karena didalam proses memaksimalkan nilai saham perusahaan tidak jarang akan muncul konflikkepentingan antara manajer dan pemegang saham (pemilik perusahaan). Tidak jarang pihak manajemen yaitu manajerperusahaan mempunyai tujuan dan kepentingan lain yang bertentangan dengantujuan utama perusahaan dan sering mengabaikan kepentingan pemegang saham. Perbedaan kepentingan antara manajer dan pemegang saham ini mengakibatkantimbulnya konflik, hal tersebut terjadi karenamanajer mengutamakan kepentingan pribadi, sebaliknya pemegang saham tidakmenyukai kepentingan pribadi dari manajer karena apa yang dilakukan manajertersebut akan menambah biaya bagi perusahaan sehingga menyebabkanpenurunan keuntungan perusahaan dan berpengaruh terhadap harga saham (Jensen dan Meckling, 2004).

Industri rokok merupakan industri yang memiliki peranan penting dalam kegiatan perekonomian Negara Indonesia. Dalam salah satu laporan tahunan perusahaan rokok yang terdaftar pada BEI (Bursa Efek Indonesia) tahun 2011, rokok merupakan barang konsumsi sebagian 
besar masyarakat Indonesia. Dari total penduduk yang mencapai lebih dari 240 juta jiwa diperkirakan 65\% atau kurang lebih 75 juta jiwa orang laki-laki dewasa di Indonesia adalah perokok. Sehingga industri ini memiliki potensi yang sangat besar untuk berkembang, disamping itu pendapatan dalam negeri sebagian besar berasal dari sektor industri rokok, dimana industri rokok sebagai penyumbang dana terbesar dalam pendapatan pajak negara setiap tahunnya. Tahun 2011 penerimaan cukai yang berasal dari industri rokok tercatat sebanyak Rp. 65 triliun. Tenaga kerja yang terserap oleh industri rokok yang berjumlah sekitar 3000 perusahaan yang tersebar di Indonesia mencapai sedikitnya 6 juta pekerja (www.kompas.com).

Tabel 1. Harga Saham Perusahaan Rokok BEI

\begin{tabular}{|c|c|c|c|c|c|c|c|c|}
\hline \multirow{2}{*}{ No } & Kode & \multicolumn{7}{|c|}{ Tahun (dalam jutaan rupiah) } \\
\cline { 3 - 9 } & & 2005 & 2006 & 2007 & 2008 & 2009 & 2010 & 2011 \\
\hline 1. & GGRM & $\begin{array}{c}11.65 \\
0\end{array}$ & 10.200 & 8.500 & 4.250 & 21.550 & 40.000 & 62.050 \\
\hline 2. & HMSP & 8.900 & 9.700 & 14.300 & 8.100 & 10.400 & 28.150 & 39.000 \\
\hline 3. & RMBA & 135 & 310 & 560 & 520 & 650 & 800 & 790 \\
\hline
\end{tabular}

Dari Tabel diatas dapat diketahui bahwasanya harga saham dari tahun ke tahun mengalami pergeseran, baik itu pada PT. Gudang Garam, PT. HM Sampoerna, maupun PT. Beontoel Indonesia. Penurunan harga saham yang terjadi disebabkan karena kondisi ekonomi makin memburuk sehingga laba yang dihasilkan perusahaan cenderung menurun, sehingga para investor enggan untuk berinvestasi dan adanya kondisi intern perusahaan seperti pengambilan keputusan dan keuntungan perusahaan, kualitas produk, posisi persaingan perusahaan di pasar, hubungan kerja pihak perusahaan dengan karyawan, sumber bahan mentah, peraturan-peraturan pemerintah. Serta ada juga kenaikan pada nilai harga saham, hal ini dikarenakan dalam melakukan investasi dalam bentuk saham investor harus melakukan analisis terhadap faktor yang dapat mempengaruhi kondisi perusahaan, sehingga dapat meminimalisasi kerugian yang dapat timbul dari adanya fluktuasi pertumbuhan dan perkembangan perusahaan yang bersangkutan.

Harga saham suatu perusahaan mencerminkan nilai perusahaan dimata para investor, apabila harga saham suatu perusahaan tinggi, maka nilai perusahaan dimata investor juga baik dan begitu juga sebaliknya, oleh karena itu harga saham merupakan hal yang penting bagi perusahaan. Faktor EPS, ROE dan Kepemilikan Institusional merupakan salah satu indikasi yang dapat menyebabkan naik dan turunnya harga saham. Hal ini diperkuat dengan penelitian terdahulu yang dilakukan oleh Dwiatma Kurniawan (2011) yang menjelaskan bahwasannya variabel EPS dan ROE berpengaruh secara signifikan terhadap harga saham, selaras dengan hasil penelitian Angrawit Kusumawardani (2011). Dalam penelitian lainnya Wahyu Chandra Wibowo (2011) membuktikan bahwasannya variabel struktur kepemilikan saham juga mempengaruhi terhadap harga saham. Oleh karena itu, peneliti tertarik untuk meneliti dengan 
judul "Pengaruh EPS, ROE, dan Struktur Kepemilikan Institusional saham Terhadap Harga Saham Pada Perusahaan Rokok Yang Go Public Di BEI.”

\section{RUMUSAN MASALAH}

Berdasarkan latar belakang
masalah yang diuaraikan maka
dirumuskan masalah sebagai berikut :

1. Apakah faktor Earning per Share (EPS), berpengaruh pada harga saham ?

2. Apakah faktor Return on Equity (ROE), berpengaruh pada harga saham?

3. Apakah Kepemilikan Institusional saham memiliki pengaruh terhadap Harga Saham ?

4. Variabel mana yang paling dominan mempengaruhi harga saham ?

\section{TINJAUAN TEORITIS}

\section{Harga Saham}

Saham merupakan salah satu bentuk efek atau surat berharga yang diperdagangkan dipasar modal (bursa). Laba bersih per saham adalah Laba bersih setelah bunga pajak di bagi dengan jumlah lembar saham yang beredar. Pengukuran dari variabel harga saham ini yaitu harga penutupan saham (closing price) tiap perusahaan yang diperoleh dari harga saham pada periode akhir tahun.Hargasaham merupakan harga yang terjadi di pasar bursa pada saat tertentu yang ditentukan oleh pelaku pasar. Nilai saham ditentukan oleh permintaan dan penawaran saham yang bersangkutan di pasar bursa. Menurut Widoatmojo (2005), nilai saham adalah nilai penyertaan atau kepemilikan seseorang dalam suatu perusahaan. Sedangkan harga saham adalah harga jual dari investor yangsatu dengan yang lain, harga pasar terjadi setelah saham tersebut dicatatkan ke bursa efek di pasar sekunder.

Sedangkan menurut Dominic (2008) harga saham adalah pembagian antara modal perusahaan dan jumlah saham yang diterbitkan. Harga saham merupakan hasil pembagian antara modal dan jumlah saham yang disebut harga nominal, pada saat emiten menerbitkan saham, emiten tidak harus menjual saham dengan harga nominal. Emiten dapat menjual sahamnya 150\%, $200 \%$ bahkan $400 \%$ dari nilai nominal, tergantung pada permintaan pasar. Ini yang disebut harga pasar. Jadi dapat disimpulkan bahwa harga saham yang diterbitkan setiap harinya adalah nilai pasar.

\section{Faktor Penggerak Harga Saham}

Cara terbaik dalam mendapatkan keuntungan (capital again) adalah membeli ketika harga akan naik lalu menjualnya ketika harganya akan turun. Namun untuk memperkirakan kapan harga sebuah saham akan naik atau turun bukanlah hal yang mudah. Ada beberapa faktor yang harus disadari oleh setiap investor. Faktor tersebutlah yang menjadi salah satu daya yang memicu berfluktuasinya harga saham.

Salah satu faktor yang memicu berfluktuasinya harga saham adalah kondisi fundamental emiten. Faktor fundamental adalah faktor yang berkaitan langsung dengan kinerja emiten itu sendiri (Arifin, 2004). Semakin baik kinerja emiten maka akan semakin besar pengaruhnya terhadap kenaikan harga saham. Begitu pula sebaliknya, semakin menurun kinerja emiten maka, semakin besar kemungkinan merosotnya harga saham yang diperdagangkan. Selain itu keadaan emiten akan menjadi tolak ukur seberapa besar resiko yang akan ditanggung oleh investor. Faktor fundamental dapat dilihat dari kondisi 
keuangannya, strategi bisnis perusahaan tersebut, produknya, manajemen hingga keunggulan lainnya yang bersifat comparative advantage.

Dan juga menurut Sitompul dan Wien (2004), dalam analisis fundamental harga saham sangat dipengaruhi oleh beberapa unsur, yaitu :

a. Kebijakan deviden perusahaan

b. Nilai buku dari asset dan asset perusahan

c. Cash flow dan

d. Tingkat laba yang dicapai perusahaan

Struktur Kepemilikan

\section{Earning per share (EPS)}

Earnngs per Share (EPS)

merupakan perbandingan antara pendapatan yang dihasilkan (laba bersih) dan jumlah saham yang beredar. Earnings per Share (EPS) menggambarkan profitabilitas perusahaan yang tergambar pada setiap lembar saham. Menurut Dictionary of Accounting (Abdultah, 2009) laba bersih per saham adalah pendapatan bersih perusahaan selama setahun dibagi dengan jumlah rata-rata lembar saham yang beredar, dengan pendapatan bersih tersebut dikurangi dengan saham preferen yang diperhitungkan untuk tahun tersebut.

Menurut Baridwan (1992:333), laba bersih per saham adalah Jumlah pendapatan yang diperoleh dalam satu periode untuk tiap lembar saham yang beredar, dan akan dipakai oleh pimpinan perusahaan untuk menentukan besarnya dividen yang akan dibagikan.Earnings per Share (EPS) dihitung dengan rumus berikut (Tjiptono Darmadji dan Hendy $M$. Fakhruddin, 2006) :

EPS $=\frac{\text { Laba bersih setelah bunga dan pajak }}{\text { Jumlah saham beredar }}$

Return on Equity (ROE)
Return on Equity (ROE) merupakan rasio keuangan yang banyak digunakan untuk mengukur kenerja perusahaan, khususnya menyangkut profitabilitas perusahaan. Return on equity (ROE) adalah suatu pengukuran dari penghasilan (income) yang tersedia bagi pemilik perusahaan (baik pemegang saham biasa maupun saham preferen) atas modal yang mereka investasikan di dalam perusahaan. ROE ini adalah rasio untuk mengukur besarnya pengembalian terhadap investasi para pemegang saham. Angkatersebut menunjukkan seberapa baik manajemen memanfaatkan investasi para pemilik perusahaan. Secara umum tentunya semakin tinggi return atau penghasilan yang diperoleh maka semakin baik kedudukan pemilik perusahaan (Fatma, 2009).

Return on Equity (ROE) dapat di rumuskan sebagai berikut (Tjiptono Darmadji dan Hendy $M$. Fakhruddin, 2006) :

ROE $=\frac{\text { Laba bersih setelah bunga dan pajak }}{\text { Ekuitas }}$ Perhitungannya ROE secara umum dihasilkan dari pembagian laba dengan ekuitas selama setahun terakhir. Cara menghitungnya memang sangat mudah, dimana dengan memahami ROE secara mendalam akan ditemukan tiga hal pokok:
a. Kemampuan perusahaan menghasilkan laba (profitability).
b. Efisiensi perusahaan dalam mengelola aset (assets management).
c. Hutang yang dipakai dalam melakukan usaha (financial leverage).

Kepemilikan Institusional 


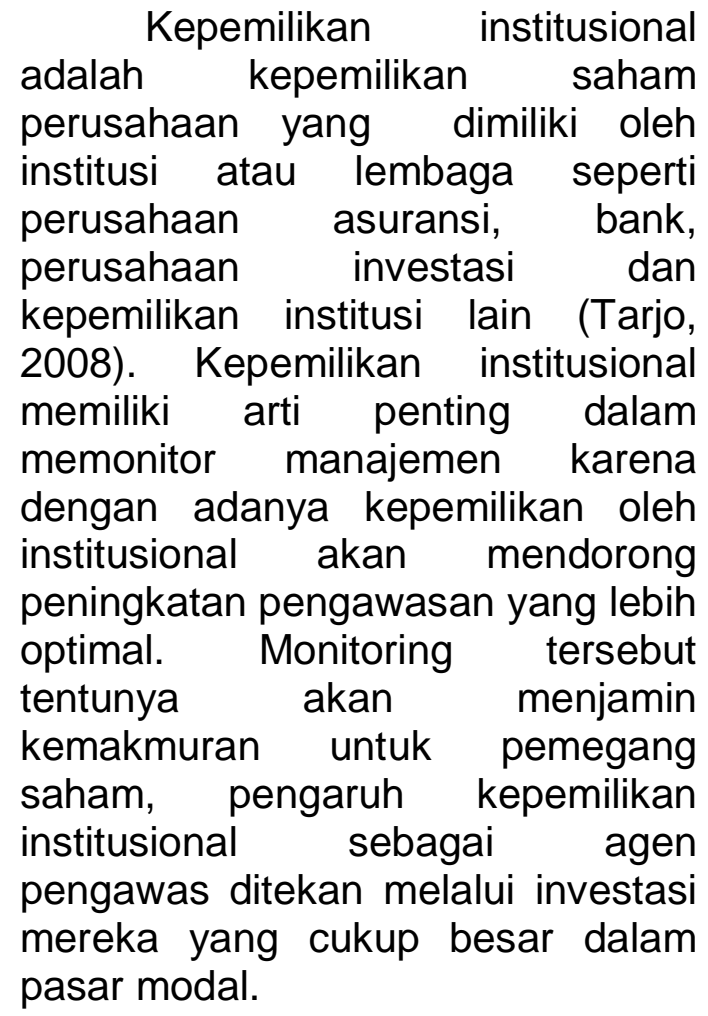

Tingkat kepemilikan

institusional yang tinggi akan menimbulkan usaha pengawasan yang lebih besar oleh pihak investor institusional sehingga dapat menghalangi perilaku opportunistic manajer. Menurut Shleifer and Vishny (dalam Barnae dan Rubin, 2005) bahwa institutional shareholders, dengan kepemilikan saham yang besar, memiliki insentif untuk memantau pengambilan keputusan perusahaan. Begitu pula penelitian Wening (2009) Semakin besar kepemilikan oleh institusi keuangan maka semakin besar pula kekuatan suara dan dorongan untuk mengoptimalkan nilai perusahaan.

\section{Hubungan antara Harga Saham, EPS, ROE dan Kepemilikan Institusional}

Harga saham merupakan harga yang terjadi di pasar bursa pada saat tertentu yang ditentukan oleh pelaku pasar. Nilai saham ditentukan oleh permintaan dan penawaran saham yang bersangkutan di pasar bursa. Menurut Widoatmojo (2005), nilai saham adalah nilai penyertaan atau kepemilikan seseorang dalam suatu perusahaan. Sedangkan harga saham adalah harga jual dari investor yangsatu dengan yang lain, harga pasar terjadi setelah saham tersebut dicatatkan ke bursa efek di pasar sekunder. Semakin banyak investor yang berminat pada saham tersebut maka semakin tinggi pula harga yang terbentuk.

Seorang investor sebelum memutuskan untuk berinvestasi yang pertama kali dianalisis adalah kinerja keuangan dari perusahaan tersebut. Variabel EPS memberikan informasi tentang suatu perusahaan mengenai besarnya laba bersih perusahaan yang siap dibagikan pada semua pemegang saham. EPS merupakan salah satu hal utama yang diperhatikan investor sebelum membuat keputusan investasinya di suatu perusahaan karena investor tentunya mengharapkan pengembalian atau return yang tinggi dari investasinya sehingga investor akan lebih tertarik untuk berinvestasi di perusahaan yang mempunyai EPS lebih tinggi. Apabila EPS suatu perusahaan dinilai tinggi oleh investor, maka hal ini akan menyebabkan harga saham perusahaan tersebut cenderung bergerak naik (Taratanika, 2009).

Rasio ROE digunakan untuk mengukur kemampuan modal dalam menghasilkan pendapatan. ROE menggambarkan kemampuan modal sendiri untuk menghasilkan keuntungan bagi pemegang saham, karena dalam ROE yang digunakan sebagai pengukur efisiensi adalah besarnya laba bersih dari jumlah modal yang digunakan perusahaan. 
Jadi, ROE merupakan tingkat hasil pengembalian investasi bagi pemegang saham (Sa'diyah, 2010). Artinya semakin besar ROE semakin baik pula manajemen perusahaan karena dari modal yang dikelolah di hasilkan pendapatan yang optimal.

\section{Struktur kepemilikan saham} secara langsung dapat mempengaruhi, perusahaan, dengan kepemilikan institusional yang besar didalam struktur perusahaan mengindikasikan kemampuannya untuk memonitor manajemen. Semakin besar kepemilikan institusional maka semakin efisien pemanfaatan aktiva perusahaan dan diharapkan juga dapat bertindak sebagai pencegahan terhadap pemborosan yang dilakukan oleh manajemen.
Jadi dapat disimpulkan bahwasannya harga saham dipengaruhi oleh kinerja keuangan, sedangkan secara tidak langsung kinerja keuangan tersebut dipengaruhi oleh struktur kepemilikan saham yang nantinya akan mendominasi seluruh kebijakan perusahan.

Berdasarkan pemikiran tersebut, maka kerangka berpikir dalam penelitian ini dapat dikemukakan sebagai berikut: Harga saham (Y) dipengaruhi oleh Earnings per Share $\left(\mathrm{X}_{1}\right)$, Return On Equity $\left(\mathrm{X}_{2}\right)$ dan Kepemilikan Institusional. Secara sistematis kerangka pemikiran dalam penelitian ini dapat dilihat pada gambar 2.1 berikut ini:

\section{Model Kerangka Konseptual Penelitian}

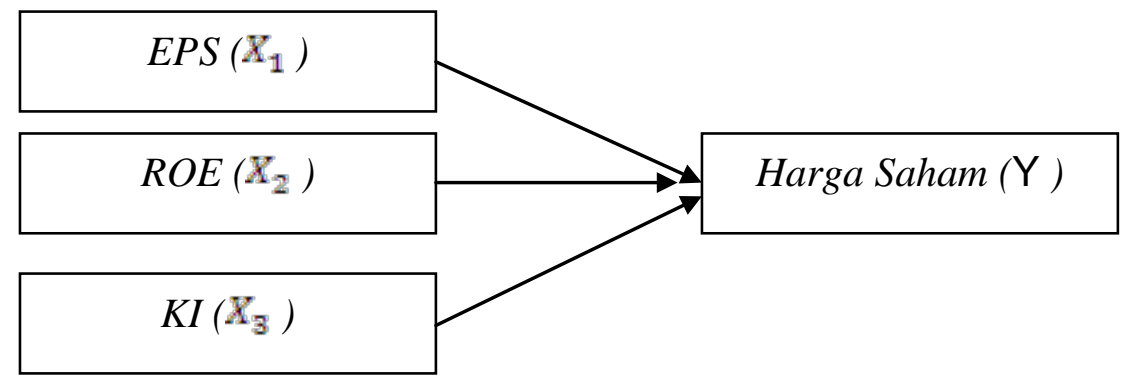

Keterangan :

$X_{1}=$ Earning per Share (EPS)

$X_{2}=$ Return on Equity (ROE)

$X_{3}=$ Kepemilikan Institusional (KI)

$Y=$ Harga Saham

\section{A. Hipotesis}

Dari uaraian diatas, hipotesis yang akan diuji dalam penelitian ini adalah :

1. Diduga bahwa variabel EPS, ROE dan KI mempunyai pengaruh yang signifikan secara individual (parsial) terhadap harga saham.

2. Diduga bahwa variabel EPS mempunyai pengaruh yang dominan terhadap harga saham. 
METODE PENELITIAN

\section{A. Jenis Penelitian}

Berdasarkan perumusan masalah dan tujuan yang ingin dicapai dalam penelitian ini, maka penelitian ini menggunakan jenis penelitian eksplanatif asosiatif, dimana hubungan antara variabelnya bersifat kausalitas. Menurut Husein (2001:63) "Desain kausal berguna untuk menganalisis hubungan antar satu variabel dengan variabel lainnya atau bagaimana satu variabel mempengaruhi variabel lainnya".Dalam penelitian ini peneliti mengembangkan konsep dan menghimpun fakta.

\section{B. Populasi dan Sampel Penelitian}

Populasi dalam penelitian ini adalah seluruh perusahaan rokok yang listing di BEl tahun 2005 sampai dengan tahun 2011.

Sampel adalah bagian dari populasi yang dijadikan subyek penelitian sebagai wakil daripada anggota

populasi (Supardi,2005:103). Dalam penelitian ini teknik penenetuan sampel yang digunakan adalah teknik purposive sampling atau teknik sampling bertujuan.Teknik ini digunakan apabila anggota sampel yang dipilih secara khusus berdasarkan tujuan penelitiannya. Dalam teknik purposive sampling peneliti menggunakan pertimbanganpertimbangan dengan memberi batas-batas atau kriteria tertentu berdasarkan ciri-ciri subyek yang akan dijadikan sampel penelitian. Adapun kriteria-kriteria yang ditetapkan agar perusahaan dapat dijadikan sampel penelitian, yaitu:

1. Perusahaan rokok yang terdaftar di BEI selama periode penelitian yaitu tahun 2005 sampai dengan tahun 2011.

2. Perusahaan melaporkan laporan keuangan secara lengkap dan telah diaudit selama periode penelitian yaitu tahun 2005 sampai dengan tahun 2011.

3. Terdapat close price per tahun mulai tahun 2005 sampai dengan tahun 2011.

4. Terdapat struktur kepemilikan institusional dalam struktur kepemilikan saham.

Dari kriteria yang telah ditetapkan diatas maka perusahaan yang dapat digunakan sebagai sampel dalam penelitian ini adalah :

Tabel 2. Sampel Penelitian

\begin{tabular}{|c|l|l|}
\hline No & Kode Perusahaan & \multicolumn{1}{|c|}{ Nama Perusahaan } \\
\hline 1. & GGRM & PT. Gudang Garam \\
\hline 2. & HMSP & PT. HM Sampoerna \\
\hline 3. & RMBA & PT. Beontoel Indonesia \\
\hline
\end{tabular}

Sumber : BEI 
VARIABEL PENELITIAN

1. Harga Saham

Saham merupakan salah satu bentuk efek atau surat berharga yang diperdagangkan dipasar modal (bursa). Pengukuran dari variabel harga saham ini yaitu harga penutupan saham (closing price) tiap perusahaan yang diperoleh dari harga saham pada periode akhir tahun.

2. Earning per Share (EPS)

Earning per Share (EPS) adalah rasio pasar yang menunjukkan bagian laba untuk setiap saham. Nilai Earning per Share (EPS) dalam penelitian ini berasal dari perbandingan antara laba bersih setelah pajak dengan jumlah yang beredar. Rasio ini secara sistematis dapat di formulasikan sebagai berikut (Tjiptono Darmadji dan Hendy $M$. Fakhruddin, 2006)

EPS $=\frac{\text { Laba bersih setelah bunga dan pajak }}{\text { Jumlah saham beredar }}$

3. Return on Equity (ROE)

Return on Equity (ROE) adalah rasio profitabilitas yang digunakan untuk mengukur tingkat efektivitas perusahaan dalam menghasilkan keuntungan dengan memanfaatkan ekuitas. Nilai Return on Equity (ROE) dalam penelitian ini berasal dari perbandingan antara laba bersih setelah pajak dengan modal sendiri yang dimiliki emiten dalam satu tahun tertentu. Return on Equity (ROE) untuk mengukur kemampuan perusahaan untuk menghasilkan laba atas modalnya sendiri. Return on Equity (ROE) dapat di rumuskan sebagai berikut
(Tjiptono Darmadji dan Hendy M.

Fakhruddin, 2006) :

ROE $=\frac{\text { Laba bersih setelah bunga dan pajak }}{\text { Ekuitas }}$

4. Kepemilikan Institusional

Kepemilikan institusional adalah kepemilikan saham perusahaan yang dimiliki oleh institusi atau lembaga seperti perusahaan asuransi, bank, perusahaan investasi dan kepemilikan institusi lain (Tarjo, 2008). Kepemilikan institusional memiliki arti penting dalam memonitor manajemen karena dengan adanya kepemilikan olehinstitusional akan mendorong peningkatan pengawasan yang lebih optimal.Monitoring tersebut tentunya akan menjamin kemakmuran untukpemegang saham, pengaruh kepemilikan institusional sebagai agen pengawas ditekan melalui investasi mereka yang cukup besar dalam pasar modal.Kepemilikan Institusional sendiri dapat dirumuskan sebagai berikut (Tarjo, 2008) :

$\mathrm{KI}=\frac{\% \text { kepemilikan institusional }}{\text { total saham }} \times 100 \%$

\section{Metode Analisis Data}

Teknik analisis data yang digunakan dalam penelitian ini menggunakan regresi linier berganda.Analisis regresi berganda digunakan untuk mengukur pengaruh atau hubungan variabel independen dengan variabel independen dengan variabel dependen. Model persamaan analisis regresi dalam penelitian ini adalah sebagai berikut:

$Y_{(t+1)}=\beta_{0}+\beta_{1} X_{t 1}+\beta_{2} X_{t 2}+\beta_{3}+$ $X_{t 3}+\varepsilon$ 
Dimana : $Y_{t+1}=$ Variabel harga saham

$$
\begin{aligned}
& \beta_{0}=\text { Konstanta } \\
& \beta_{1}=\text { Koefisien regresi }
\end{aligned}
$$

untuk Earning per share

Share (EPS)

$$
X_{t 1}=\text { Earning per }
$$

$$
\beta_{2}=\text { Koefisien regresi }
$$

untuk Return on Equity

(ROE)

$$
X_{t 2} \quad=\text { Return on Equity }
$$

$$
\beta_{3} \quad=\text { Koefisien regresi }
$$

Kepemilikan Institusional (KI)

Institusional (KI)

Uji $\mathbf{R}^{2}$

$$
X_{t 3} \quad=\text { Kepemilikan }
$$

$$
\varepsilon=\text { Eror }
$$

Dalam analisis regresi digunakan koefisien determinasi $\left(\mathrm{R}^{2}\right)$ bertujuan untuk mengukur seberapa jauh kemampuan model dalam menerangkan variabel dependen. Ghozali (2005:45).

\section{Uji-t}

Menurut Ghozali (2005:56). "Uji t digunakan untuk menentukan apakah dua sampel yang tidak berhubungan memiliki nilai rata-rata yang berbeda". Uji ini menunjukkan seberapa jauh pengaruh variabel independen secara parsial terhadap variabel dependen. Pengujian dilakukan dengan uji 2 (dua) arah, sebagai berikut :

1. Membandingkan antara $\mathrm{t}$ hitung dengan $\mathrm{t}$ tabel :

a) Bila $t$ hitung $<t$ tabel ; variabel bebas secara individu tidak berpengaruh

terhadap variabel tak bebas.

b) Bila thitung $>\mathrm{t}$ tabel ; variabel bebas secara individu berpengaruh terhadap variabel tak bebas.

2. Berdasarkan

profitabilitas

Dengan

kriteria pengambilan keputusan:

jika nilai probabilitas < 0,05 maka $\mathrm{Ha}$ diterima $\mathrm{Ho}$ ditolak

jika nilai probabilitas > 0,05 maka $\mathrm{Ha}$ ditolak $\mathrm{Ho}$ diterima

\section{HASIL DAN PEMBAHASAN PENELITIAN}

\section{Deskripsi hasil penelitian Harga Saham}

Nilai rata-rata harga saham perusahaan sampel selama tahun pengamatan adalah 13.492,3. Perusahaan sampel yang memiliki rata-rata harga saham tertinggi selama tahun pengamatan adalah PT. Gudang Garam Tbk. yaitu sebesar Rp. 22.600,-. Sedangkan nilai rata-rata haraga saham terendah selama tahun pengamatan dipegang oleh PT. Beontoel Indonesia dengan rata-rata harga saham yaitu sebesar Rp. 941,25. 
Tabel 3. Harga Saham Perusahaan Rokok di BEI Periode 2005-2011

\begin{tabular}{|c|c|c|c|c|c|c|c|c|}
\hline \multirow{2}{*}{$\begin{array}{c}\text { Kode } \\
\text { Perusaha } \\
\text { an } \\
\end{array}$} & \multicolumn{7}{|c|}{ Harga Saham } & \multirow{2}{*}{$\begin{array}{l}\text { Rata- } \\
\text { rata }\end{array}$} \\
\hline & 2005 & 2006 & 2007 & 2008 & 2009 & 2010 & 2011 & \\
\hline GGRM & 11.650 & 10.200 & 8.500 & 4.250 & 21.550 & 40.000 & 62.050 & 22.600 \\
\hline HMSP & 8.900 & 9.700 & 14.300 & 8.100 & 10.400 & 28.150 & 39.000 & $\begin{array}{c}16.935, \\
7\end{array}$ \\
\hline RMBA & 135 & 310 & 560 & 520 & 650 & 800 & 790 & 941,25 \\
\hline $\begin{array}{c}\text { Rata-rata } \\
\text { Total }\end{array}$ & 6.895 & $6.736,6$ & $4.953,3$ & 4.290 & 10.866 & 22.983 & 33.946 & $\begin{array}{c}13.492, \\
3\end{array}$ \\
\hline
\end{tabular}

\section{Earning per Share (EPS)}

Tabel 4. Earning per Share (EPS) Perusahaan Rokok di BEI Periode 2005-2011

\begin{tabular}{|c|c|c|c|c|c|c|c|c|}
\hline \multirow{2}{*}{$\begin{array}{c}\text { Kode } \\
\text { Perusaha } \\
\text { an }\end{array}$} & \multicolumn{7}{|c|}{ Earning per Share (EPS) } & \multirow{2}{*}{$\begin{array}{c}\text { Rata- } \\
\text { rata }\end{array}$} \\
\hline & 2005 & 2006 & 2007 & 2008 & 2009 & 2010 & 2011 & \\
\hline GGRM & 982 & 524 & 750 & 977 & 1796 & 2155 & 2544 & $\begin{array}{l}1.389,7 \\
1\end{array}$ \\
\hline HMSP & 544 & 805 & 827 & 889 & 1161 & 1456 & 1840 & $\begin{array}{l}1.074,5 \\
7\end{array}$ \\
\hline RMBA & 16 & 12 & 36 & 26 & -22 & 30 & 42 & 20 \\
\hline $\begin{array}{l}\text { Rata-rata } \\
\text { Total }\end{array}$ & 514 & 447 & 537,66 & 630,66 & 978,33 & $1.213,6$ & $1.475,3$ & 828,09 \\
\hline
\end{tabular}

Sumber : ICMD

Nilai rata-rata EPS perusahaan selama tahun pengamatan adalah Rp. 828,09 Perusahaan yang memilki ratarata EPS tertinggi adalah PT. Gudang Garam Tbk. yaitu sebesar Rp. 1.389,71. Sedangkan nilai rata-rata EPS terendah selama tahun pengamatan adalah PT.
Beontoel Indonesia sebesar Rp. 20,-. Rata-rata EPS seluruh perusahaan sampel dari tahun ke tahun terus mengalami peningkatan, hal ini memberikan indikasi bahwa perkembangan pertumbuhan beberapa perusahan sampel sudah stabil.

\section{Return on Equity}

Tabel 5. Return on Equity(ROE) Perusahaan Rokok di BEI Periode 2005-2011

\begin{tabular}{|l|l|l|l|l|l|l|l|l|}
\hline \multirow{2}{*}{$\begin{array}{c}\text { Kode } \\
\text { Perusahaan }\end{array}$} & 2005 & 2006 & 2007 & 2008 & 2009 & 2010 & 2011 & $\begin{array}{c}\text { Rata- } \\
\text { rata }\end{array}$ \\
\cline { 2 - 10 } & 14,41 & 7,66 & 10,22 & 12,12 & 18,88 & 19,56 & 20,19 & 14,72 \\
\hline GGRM & 52,08 & 62 & 44,49 & 48,4 & 48,63 & 62,87 & 79,04 & 56,78 \\
\hline HMSP & 9,71 & 12,22 & 15,76 & 13,82 & $-7,74$ & 10,27 & 13,61 & 9,66 \\
\hline RMBA & 25,4 & 27,29 & 23,49 & 74,34 & 19,92 & 30,9 & 37,61 & 27,05 \\
\hline $\begin{array}{l}\text { Rata-rata } \\
\text { Total }\end{array}$ & & \multicolumn{7}{|c|}{ Return on Equity (ROE) } \\
\hline
\end{tabular}

Sumber : ICMD 
Nilai ROE keseluruhan perusahaan sampel rata-rata adalah $27,05 \%$. Perusahaan sampel yang mempunyai rata-rata ROE tertinggi adalah selama tahun pengamatan adalah PT. HM Sampoerna dengan rata-rata sebesar 56,78\%,-. Sedangkan nilai ratarata ROE terendah adalah PT. Beontoel Indonesia sebesar 9,66\%,-. Rata-rata ROE keseluruhan perusahaan sampel menunjukkan peningkatan pada tahuntahun terakhir pengamatan.

\section{Kepemilikan Institusional}

Tabel 6. Kepemilikan Institusional Perusahaan Rokokdi BEI Periode 2005-2011

\begin{tabular}{|c|c|c|c|c|c|c|c|c|}
\hline \multirow{2}{*}{$\begin{array}{c}\text { Kode } \\
\text { Perusahaan }\end{array}$} & \multicolumn{7}{|c|}{ Earning per Share (EPS) } & \multirow{2}{*}{$\begin{array}{c}\text { Rata- } \\
\text { rata }\end{array}$} \\
\hline & 2005 & 2006 & 2007 & 2008 & 2009 & 2010 & 2011 & \\
\hline GGRM & 72,12 & 72,12 & 72,12 & 72,12 & 73,06 & 75,55 & 75,55 & 73,23 \\
\hline HMSP & 44,51 & 97,95 & 97,95 & 98,04 & 98,18 & 98,18 & 98,18 & 90,04 \\
\hline RMBA & 17,38 & 17,38 & 50,87 & 65,87 & 23,5 & 98,96 & 98,96 & 53,27 \\
\hline $\begin{array}{l}\text { Rata-rata } \\
\text { Total }\end{array}$ & 44,67 & 62,48 & 73,64 & 78,67 & 64,91 & 90,89 & 90,89 & 72,18 \\
\hline
\end{tabular}

Sumber : ICMD

Nilai Kepemilikan Institusional seluruh perusahaan sampel adalah 72,18\%. Perusahaan sampel yang mempunyai nilai rata-rata tertinggi adalah PT. HM. Sampoerna yaitu 90,04\%. Sedangkan nilai kepemilikan institusional terendah adalah PT. Beontoel Indonesia yaitu 53,27\%.

\section{Analisis Data}

\section{a. Uji Normalitas}

\begin{tabular}{|c|c|c|c|c|c|}
\hline & & $\mathrm{HS}$ & EPS & ROE & $\mathrm{KI}$ \\
\hline $\mathrm{N}$ & & 21 & 21 & 21 & 21 \\
\hline \multirow[t]{2}{*}{ Normal Parameters $\mathrm{a}, \mathrm{b}$} & Mean & 13357,86 & 828,0952 & 27,0571 & 72,3119 \\
\hline & Std. Deviation & 16378,29 & 773,76087 & 23,20254 & 27,49344 \\
\hline Most Extreme & Absolute &, 256 &, 179 &, 283 &, 212 \\
\hline \multirow[t]{2}{*}{ Differences } & Positive & ,256 &, 179 &, 283 &, 166 \\
\hline & Negative &,- 210 &,- 136 &,- 154 &,- 212 \\
\hline Kolmogorov-Smirnov Z & & 1,172 & ,818 & 1,297 & ,969 \\
\hline Asymp. Sig. (2-tailed) & &, 128 &, 515 & ,069 & , 304 \\
\hline
\end{tabular}

a. Test distribution is Normal.

b. Calculated from data.

Dari tabel One-sample Kolmogorov diatas dapat diketahui bahwasannya taraf signifikansi lebih besar dari pada 0,05, maka dapat disimpulkan bahwa variabelvariabel dalam penelitian ini berdistribusi normal.

\section{b. Uji Asumsi Klasik}

1. Multikolinearitas

Tujuan dari uji adalah untuk mengetahui apakah terdapat antara kolerasi anatara variabel bebas. Jika terjadi korelasi yang signifikan antar variabel bebas maka terjadi problem multikolinearitas. 
Tabel7. Hasil Uji Multikonealiritas

\begin{tabular}{|l|l|l|l|l|}
\hline \multirow{2}{*}{ Variabel bebas } & \multirow{2}{*}{$t$} & \multirow{2}{*}{ Sig } & \multicolumn{2}{|l|}{ Collinearity statistic } \\
\cline { 3 - 5 } & &, 000 &, 772 & 1,295 \\
\hline EPS & 9,343 &, 000 &, 662 & 1,512 \\
\hline ROE &, 126 &, 902 &, 653 & 1,532 \\
\hline KI &,- 854 &, 405 & & \\
\hline $\mathrm{R}=, 928$ & & \\
R Square $=, 862$ \\
Ajusted R Square $=, 837$ \\
F Statistik $=35.272$ \\
Sig. F $=0.000$
\end{tabular}

Dari hasil uji tersebut, ditemukan bahwa nilai varian inflation factor (VIF) tidak lebih dari 10 dan tidak kurang dari 0,1. Maka dapat dikatakan bahwa model regresi terbebas dari problem multikolinearitas.

2. Hetereokedastisitas

Uji heteroskedastisitas bertujuan untuk menguji apakah dalam sebuah model regresi terjadi ketidaksamaan varians dari residual pada satu observasi ke observasi yang lain. Jika varians dari residual satu pengamatan ke pengamatan lainnya tetap maka disebut homoskedastisitas, demikian sebaliknya jika varians berbeda disebut heteroskedastisitas.

\section{Gambar 4 Hasil Uji Heterokedastisitas}

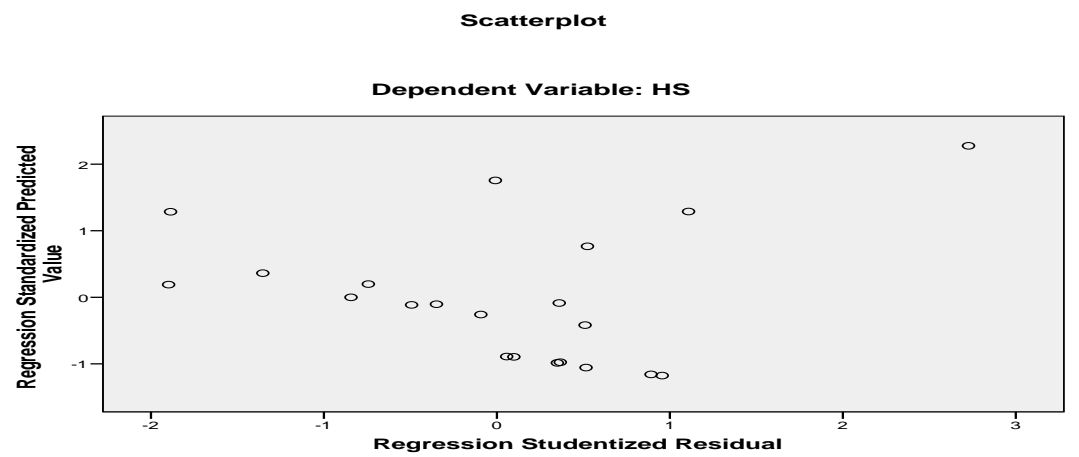

Dengan melihat gambar diatas dapat dilihat bahwa tidak adanya pola yang jelas, serta titik-titik menyebar di atas dan di bawah 0 pada sumbu $\mathrm{Y}$, maka dapat disimpulkan tidak terjadi heteroskedastisitas pada model regresi ini.

\section{Uji Autokorelasi}

untuk mengetahui ada tidaknya korelasi antara variabel pengganggu pada periode tertentu dengan variabel pengganggu periode sebelumnya.Uji autokorelasi dilakukan dengan menghitung nilai Durbin-Watson statistik berdasarkan kriteria DurbinWatson. 
Tabel 8. Hasil Uji Autokorelasi

\begin{tabular}{|l|r|r|r|r|r|}
\multicolumn{7}{c|}{ Model Summary } \\
\hline Model & \multicolumn{1}{c|}{ R } & R Square & $\begin{array}{c}\text { Adjusted } \\
\text { R Square }\end{array}$ & $\begin{array}{c}\text { Std. Error of } \\
\text { the Estimate }\end{array}$ & $\begin{array}{c}\text { Durbin- } \\
\text { Watson }\end{array}$ \\
\hline 1 &, $928^{\mathrm{a}}$ &, 862 &, 837 & 6609,27533 & 1,234 \\
\hline
\end{tabular}

a. Predictors: (Constant), KI, EPS, ROE

b. Dependent Variable: HS

Hasil analisis Tabel menunjukkan nilai DW hitung sebesar 1,234 maka dinyatakan terbebas dari masalah auto korelasi dengan ketentuan $\quad-2<$ DW $<2$ untuk model

\section{Regresi Linier Berganda}

Tabel 9. Hasil Analisis Linier Berganda

\begin{tabular}{|c|l|l|l|}
\hline \multirow{2}{*}{ Model } & \multicolumn{2}{|c|}{$\begin{array}{c}\text { Unstandartdized } \\
\text { Coefficients }\end{array}$} & $\begin{array}{l}\text { Standartdized } \\
\text { Coefficients }\end{array}$ \\
\cline { 2 - 4 } & \multicolumn{1}{|c|}{$\mathrm{B}$} & \multicolumn{1}{c|}{ Std. Error } & \multicolumn{1}{c|}{ Beta } \\
\hline 1 (Constant) & 379,238 & 4173,693 & \\
\hline EPS & 20,310 & 2,174 &, 960 \\
\hline ROE & 9,837 & 78,308 &, 014 \\
\hline KI & $-56,786$ & 66,582 &,- 095 \\
\hline
\end{tabular}

Sumber : Data sekunder diolah

Berdasarkan hasil regresi yang ditunjukkan pada tabel diatas, dapat diperoleh persamaan regresi sebagai berikut :

$\mathrm{Y}=379,238+20,310$ EPS $+9,837$ ROE - 56,786 KI

1) $\alpha=379,238$

Nilai konstanta regresi sebesar 379,239 menunjukkan bahwa harga saham akan mengalami kenaikan, dengan asumsi variabel lain tetap.

2) $\quad \beta_{1}=20,310$

Nilai koefisien EPS sebesar 20,310 menunjukkan bahwa jika variabel EPS berubah satu satuan atau 1\%, maka harga saham akan naik sebesar 20,310,- dengan asumsi variabel lain tetap.
3) $\quad \beta_{2}=9,837$

Nilai koefisien ROE sebesar 9,837 menunjukkan bahwa jika variabel ROE berubah sebesar satu satuan atau $1 \%$, maka harga saham akan berubah naik sebesar. 9,837,dengan asumsi variabel lain tetap.

4) $\beta_{3}=-56,786$

Nilai koefisien KI sebesar -56,786 hal ini menunjukkan bahwa jika variabel KI berubah sebesar satu satuan atau $1 \%$, maka harga saham akan turun. 56,786,- dengan asumsi variabel lain tetap.

A. Hasil Uji Koefisien Determinasi $\left(\mathbf{R}^{2}\right)$

Koefisien determinasi $\left(\mathrm{R}^{2}\right)$ menunjukkan seberapa besar kemampuan variabel independen 
menjelaskan variabel dependen. Seperti pada tabel berikut :

Hasil Uji Koeffisien Determinasi

Model Summary

\begin{tabular}{|c|c|l|l|l|}
\hline Model & R & R Square & $\begin{array}{l}\text { Ajusted R } \\
\text { Square }\end{array}$ & $\begin{array}{l}\text { Std. Error or } \\
\text { the Estimate }\end{array}$ \\
\hline 1 &, $928(a)$ &, 862 &, 837 & 6609,27533 \\
\hline
\end{tabular}

Dari tabel diatas dapat dilihat bahwa nilai koefisien determinasi $\left(R^{2}\right)$ sebesar 0,862. Hal ini berarti variabel bebas dapat menjelaskan pola pergerakan variabel terikat yakni harga saham sebesar 86,2\%, sedangkan sisanya $13,8 \%$ dijelaskan oleh variabel lain. Sedangkan R (koefisien korelasi) menunjukkan korelasi antara pengaruh
EPS, ROE dan Kepemilikan Institusional terhadap harga saham adalah positif yaitu sebesar 92,8\% menunjukkan bahwa pengaruh/ hubungan antara variabel bebas terhadap variabel terikat adalah sangat kuat, seperti terlihat pada tabel di bawah ini:

Tabel 10. Pedoman Interpretasi Koefisien Korelasi

\begin{tabular}{|c|c|}
\hline Interval koefisien & Tingkat hubungan \\
\hline $0,00-0,199$ & Sangat rendah \\
\hline $0,20-01,399$ & Rendah \\
\hline $0,40-0,599$ & Sedang \\
\hline $0,60-0,799$ & Kuat \\
\hline $0,80-1,00$ & Sangat kuat \\
\hline
\end{tabular}

Sumber : Sugiyono (1999:149)

\section{B. Uji Hipotesis}

1. Pengujian Hipotesis pertama

Dari hasil uji t dapat diketahui variabel EPS berpengaruh secara parsial terhadap variabel harga saham dengan nilai probabilitas $<0,05$. seperti terlihat pada tabel berikut ini:

Tabel 11. Hasil Regresi untuk uji $\mathrm{t}$ (Parsial)

\begin{tabular}{|c|c|c|}
\hline $\begin{array}{l}\text { Variabel } \\
\text { bebas }\end{array}$ & t & Sig. \\
\hline EPS & 9,343 &, 000 \\
\hline ROE &, 126 &, 902 \\
\hline KI &,-854 &, 405 \\
\hline
\end{tabular}

Dari hasil uji-t yang dilakukan dapat disimpulkan bahwa secara individual (parsial) variabel yang berpengaruh terhadap harga saham adalah variabel EPS. Hal ini disebabkan tingkat signifikansi 0,000. Sedangkan variabel ROE dan KI tidak berpengaruh terhadap harga saham dikarenakan taraf signifikansi $>0,05$.

\section{Pengujian Hipotesis Kedua}

Pengujian hipotesis yang kedua untuk menentukan variabel bebas mana yang paling dominan mempengaruhi harga saham. Pengujian ini ditentukan dengan melihat pada nilai Standardized coefficientatau beta pada masing-masing variabel bebas yang diteliti. 
Tabel 12. Nilai stardartdized coefficient variabel bebas

\begin{tabular}{|l|c|}
\hline \multirow{2}{*}{ Variabel } & $\begin{array}{c}\text { Stardartdized } \\
\text { coefficient }\end{array}$ \\
\cline { 2 - 2 } & Beta \\
\hline EPS & 0,960 \\
\hline ROE & 0,014 \\
\hline KI & $-0,095$ \\
\hline
\end{tabular}

Dari tabel diatas dapat diketahui bahwa variabel EPS mempunyai nilai beta sebesar 0,960 atau yang tertinggi diantara variabel bebas lainnya. Nilai ini menunjukkan bahwa EPS mempunyai pengaruh yang dominan terhadap harga saham perusahaan rokok di BEI. Kesimpulan yang dapat diambil adalah variabel EPS terbukti sebagai variabel yang mempunyai pengaruh yang dominan terhadap harga saham perusahaan rokok.

\section{Pembahasan Hasil Penelitian}

1. Pengaruh variabel EPS, ROE dan Kepemilikan Institusional terhadap harga saham

Berdasarkan penelitian yang diuraikan diatas, maka untuk memperoleh gambaran hasil penelitian yang lebih jelas akan ditelaah lebih lanjut setiap data hasil perhitungan. Dengan melihat koefisien determinasi $\left(R^{2}\right)=0,862$ menunjukkan bahwa variabel EPS, ROE dan KI mempunyai kemampuan menjelaskan pola pergerakan harga saham sebesar 86,2\%, sedangkan sisanya 13,8\% dijelaskan oleh variabel lain. Tingginya nilai $R^{2}$ memberikan gambaran bahwa pola pergerakan harga saham dapat ditentukan atau dipengaruhi oleh variabel EPS, ROE dan KI.
Sedangkan pengaruh variabe bebas secara individu (parsial) terhadap harga saham akan dikemukakan berikut ini :

a) Earning Per Share (EPS)

Dari hasil uji t diperoleh tingkat signifikansi sebesar 0,000, yang artinya secara parsial variabel EPS mempunyaipengaruh yang signifikan terhadap harga saham. Dan juga variabel bebas EPS mempunyai koefosien regresi yang bertanda positif, hal ini menunjukkan bahwa kenaikan EPS akan mendorong kenaikan harga saham.

Hasil penelitian ini mendukung teori yang di kemukakan oleh P.jonesdalam husnan (2005:328) yang menyatakan bahwa umumnya terdapat korelasi yang kuat antara pertumbuhan laba (EPS) dengan pertumbuhan harga saham. Hasil inijuga didukung oleh penelitian sebelumnya yang di lakukan oleh Munifatur Rosyidah (2005) dan Aang Faridl Z. (2007) yang menyatakan bahwavariabel EPS mempunyai pengaruh yang signifikan terhadap harga saham. Hal ini mengindifkasikan tidak terjadinya penyimpangan dari teori yang umumnya berlaku, yaitu perubahan laba mempunyai pengaruh yang positif terhadap perkembangan harga saham. Dan juga, variabel bebas EPS yang mempnyai pengaruh positif terhadap harga saham menujukkan bahwa peruahaan mampu meningkatkan taraf kemakmuran investor.

b) Return on Equity (ROE)

Dari hasil uji diperoleh tingkat signifikan sebesar 0,902, yang artinya secara parsial variabel ROE tidak berpengaruh terhadap harga saham. Hasil penelitian ini 
mendukung penelitian sebelumnya yang telah dilakukan oleh Munifatur rosyidah (2005) dan Aang Faridl z. (2007),yang menyatakan bahwa variabel ROE secara parsial tidak berpengaruh terhadap harga saham. Hasil ini mengindikasikan bahwa hasil pengembalian atas ekuitas yang diperolehperusahaan tidak menyebabkan naiknya harga saham. Artinya, naik atau turunnya pengembalian atas ekuitas secara parsial tidak mempengaruhi harga saham.

c) Kepemilikan Institusional (KI)

Dari hasil uji $\mathrm{t}$ telah diperoleh variabel kepemilikan institusional menghasilkan tingkat signifikan sebesar 0,405, yang artinya secara parsial variabel kepemilikan institusional tidak mempunyai pengaruh terhadap harga saham. Hal ini sama dengan penelitian yang dikemukakan Demsetz dan Villalonga (2009) yang menyatakan bahwa kepemilikan institusional tidak berpengaruh terhadap harga saham. Selain itu Hexana Sri Lastani (2010) dan Wahyudi (2009) menemukan bahwa meskipun kepemilikan institusional tinggi namun tidak berpengaruh terhadap nilai saham perusahaan. Menurut Pound (2009:35), investor institusional mayoritas memiliki kecenderungan untuk berkompromi atau berpihak kepada manajemen dan mengabaikan kepentingan pemegang saham minoritas. Anggapan bahwa manajemen sering mengambil tindakan atau kebijakan yang non-optimal dan cenderung mengarah pada kepentingan pribadi mengakibatkan strategi aliansi antara investor institusional dengan pihak manajemen ditanggapi negatif oleh pasar. Hal ini tentunya berdampak pada penurunan harga saham perusahaan dipasar modal sehingga dengan kepemilikan institusional belum mampu menjadi mekanisme yang dapat meningkatkan nilai perusahaan.

\section{Variabel yang paling berpengaruh terhadap harga saham}

di atas, dilihat dari nilai Standardized Coefficient atau beta tampak bahwa variabel EPS mempunyai nilai beta yang tertinggi sebesar 0,960 atau tertinggi diantara variabel bebas lainnya. Oleh karena itu dapat dijelaskan bahwa pendugaan EPS sebagai variabel yang paling berpengaruh terhadap harga saham adalah benar adanya.

Dengan asumsi bahwa dari ketiga variabel bebas yang ada dalam model regresi, variabel EPS merupakan variabel yang paling berkaitan dengan harga saham yaitu laba per lembar sahamnya. Sedangkan ROE menunjukkan return yang didapat oleh emiten dengan modal sendiri, kepemilikan institusional lebih terfokus pada laba sekarang.

\section{KESIMPULAN DAN SARAN}

Berdasarkan pada hasil analisis data, kesimpulan yang bisa diambil dari hasil penelitian ini adalah bahwa harga saham pada industri rokok dipengaruhi oleh earning per share (EPS). Tingginya EPS ini mengindikasikan bahwa perusahaan mampu meningkatkan kemakmuran investor sehingga tingkat kepercayaan investor juga semakin meningkat. Hal ini akan mendorong investor untuk menanamkan modalnya ke perusahaan tersebut. Penelitian ini 
terbatas pada EPS, ROE dan kepemilikan institusional yang mempengaruhi harga saham. Sedangkan banyak faktor lain yang mempengaruhi harga saham seperti pertumbuhan laba,sehinggan disarankan bagi peneliti lain yang berminat untuk memperluas variabel yang akan digunakan untuk mengestimasi harga saham karena selain dari variabel EPS, ROE dan Kepemilikan Institusional masih banyak faktor-faktor lain mempunyai pengaruh.

\section{DAFTAR PUSTAKA}

Aang, Fadly Z. 2007. Analisis Pengaruh Variabel Fundamental terhadap Harga saham pada perusahaan Farmasi yang terdaftar di BEI periode 20002006. Skripsi, Jakarta FE. Universitas Indonesia.

Angrawit Kusuma Wardani. 2011. Analisis Pengaruh EPS, PER, ROE, ROA Terhadap Harga Saham pada Perusahaan LQ45 di BEI periode 20062010. Skripsi, Malang FE. Universitas Brawijaya.

Arifin, Ali. 2004. Membaca Saham. Yogyakarta: CV.Andi Offset.

Arikuntoro, Suharsimi. 2002. Prosedur

Penelitian : Suatu Pendekatan

Praktek.Jakarta: PT. Rineka Cipta.

Basri, dan Indriyo Gitosudarmo. 2002. Manajemen Keuangan. Yogyakarta : FE UGM.

Baridwan, Zaki. 1992. Manajemen Keuangan Perusahaan. Jakarta: PT.Raja Grafindo Persada.

Bungin, Burhan. 2009. Metodologi Penelitian Kuantitatif. Jakarta : Kencana.
Darmaji, Tjiptono dan Hendy M.Fakhruddin. 2006. Pasar Modal di Indonesia. Jakarta : Salemba Empat.

Demsetz dan Villalonga.2009. Pengaruh Kepemilikan Manajerial dan Institusional terhadap Nilai Perusahaan pada Perusahaan yang Go Public di BEI periode 2006-2008. Medan FE. Universitas Sumatera Utara.

Dominic, H., T. 2008. Berinvestasi di Bursa Saham. PT. Elex Media Komputindo, Jakarta.

Erlina dan Mulyani. 2007. Metode Penelitian Ekonomi dan Bisnis. Yogyakarta: UII Press.

Fatma Khotimatul Husna. 2009. Analisis Pengaruh Variabel Fundamental terhadap harga saham pada Perusahaan Pertambangan yang terdaftar di BEI periode 2005-2008. Malang FE. Universitas Maulana Malik Ibrahim.

Ghozali, Anwar. 2002. Metode Penelitian Kuantitatif, Kualitatif. Bandung: ALFABETA, 2005.

Halim, Abdul. 2005. Analisis Investasi. Jakarta: Salemba Empat.

Hin, L. Tian. 2008. Panduan berinvestasi saham. Edisi Terkini. PT. Elex Media Komputindo, Jakarta.

Husein, Sadad. 2001. Metodologi Penelitian Sosial. Jakarta: Bumi Aksara. 
Husnan, Suad. 2001. Dasar-Dasar Teori Portfolio dan Analisis Sekuritas. Yogyakarta: UPP AMP YKPN.

Husnan, Suad. 2005 . Dasar-Dasar Teori Portfolio dan Analisis Sekuritas. Edisi ketiga. Yogyakarta: UPP AMP YKPN.

Jogiyanto. 2003. Teori Portfolio dan Analisis Investasi. Yogyakarta: BPFEYogyakarta.

Jensen dan Meckling. 2004. Pengaruh Struktur Kepemilikan Saham terdahap Nilai Perusahaan. Jakarta: PT.Raja Grafindo Persada.

Kamaruddin, Ahmad. 2004. Pasar Modal. CV. Andi Offset.

Munifah Rosyidah. 2005. Analsis Pengaruh

RasioKeuangan

Terhadap Harga saham pada perusahaan Food ang Beverage diBEI periode 2000-2004. Medan FE. Universitas Sumatera Utara.

Rusdin. 2008. Pasar Modal. Bandung: Alfabeta.

Sunariyah. $2006 . \quad$ Pengantar Modal. Yogyakarta: UPP STIM YKPN

Sugiyono. 2007. Metode Penelitian Kuantitatif, Kualitatif Dan $R$ \& D. Bandung: ALFABETA.

Siti nur Sa'siyah. 2010. Pengaruh Good Corporate Governance Terhadap Kinerja Keuangan Perusahaan Go Publik Di Indonesia (Studi Kasus Pada Perusahaan Peringkat 20
Besar Skor CGPI). Skripsi. Pasuruan Adni. Universitas Yudharta.

Santoso, Singgih. 2001. Buku Latihan SPSS Statistic Parametric.Jakarta: PT Alex Media Komputindo. Taratanika Intan. 2009. Analisis Pengaruh EPS, DPR, PER Terhadap Harga saham pada Perusahaan yang listing di BEI Periode Tahun 20052008. Skripsi. Medan FE. Universitas Sumatera Utara.

Tandelilin, Eduardus. 2001. Analisis Investasi dan Manajemen Portofolio. Yogyakarta: BPFE-Yogyakarta.

Tambunan, Andy Porman. 2007. Menilai Harga Wajar Saham (Stock Valuation). Jakarta: PT.Elek Media Komputindo.

Wahyu Chandra Wibowo. 2011. Pengaruh Kepemilikan Manjaerial, Kepemilikan Institsional, dan Corporate Social responbility terhadap harga Saham pada perusahaan makanan dan minuman di BEI periode 2008-2010. Skripsi. Malang FE. Universitas negri Malang. www. kompas.com 